\title{
Az Állattani Szakosztály ülései (2019. december 4. - 2020. február 5.)
}

\author{
TÓTH BALÁZs* \\ Magyar Természettudományi Múzeum Állattára, 1088 Budapest, Baross u. 13. \\ E-mail: toth.balazs@nhmus.hu
}

Az előadásokról videófelvételek készülnek, amelyek szerkesztés után felkerülnek a Szakosztály nyilvános YouTube-csatornájára. Ennek megfelelően a levezető elnök minden előadóülés elején bejelenti, hogy az előadások a továbbiakban videokamerával rögzítésre kerülnek, és a felvételeken történő megjelenést a hallgatóság tagjai az ülésen történő további részvétellel vállalják. A felvételek rögzítését, szerkesztését és feltöltését SULYÁN PÉTER végzi, akinek ezúton is köszönetemet fejezem ki, mert munkájával nagymértékben megkönnyítette jelen összefoglaló elkészítését.

\section{3. előadóülés, 2019. december 4-én}

Az ülés levezető elnöke ezúttal SzÖVÉNYI GERGELY, a Szakosztály titkára volt. Nyitányként elmondta, hogy éppen az elöadóülés napján száz évvel ezelött hunyt el id. ENTZ GÉZA, a Szakosztály alapító alelnöke. Haláláig számos előadást tartott a Szakosztályban. Néhány évig a kolozsvári egyetem, és néhány évig a budapesti Mủegyetem rektora is volt.

1. KORSÓs ZOLTÁN: 250 éve született ALEXANDER VON HUMBOLDT természettudós.

HUMBOLDT első magyar nyelven megjelent műve „Az Orinoco vadonában” címü könyve volt. Előadó gyermekként jutott hozzá; ekkor még azt gondolta, milyen jó lehetett HuMBOLDT korában élni, mert rengeteg új felfedezést lehetett tenni. Később belátta, hogy egy nagy felfedezőre számos kevésbé sikeres pályatárs jutott, sőt a felfedezők életét számos veszély fenyegette útjaikon. HUMBOLDT nem kapott szeretetet édesanyjától, de próbált megfelelni elvárásainak. Az ő halála után nem sokkal indult el amerikai útjára, melyet örökségéből finanszírozott. Élete utolsó harmadában Oroszországba tett hosszú felfedezőutat, majd 1859-ben halt meg, vagyis halálának is kerek évfordulója van. Amerikai útja öt éven át tartott, ennek vége felé az Egyesült Államokban előadásokat tartott az út korábbi állomásairól. Több tízezer gyüjteményi tárgyat (és egy indián kalauzt) hozott haza. Megmászta a Chimborazo hegyet, az itt szerzett tapasztalatok is segítették felismerni a tengerszint feletti magassággal változó növényzeti övezetességet. Az ő munkássága fektette le a biogeográfia alapjait is. HUMBOLDT nem gyarmatosítási szándékkal, hanem az ismeretszerzés vágyától hajtva utazott. Hatalmas mennyiségű megfigyelést rögzített, összefüggések későbbi felfedezése céljából. Müszerparkja több ládányi terjedelmü volt. Ötvenezer levelet írt négy

\footnotetext{
*Az Állattani Szakosztály jegyzője
} 
nyelven, GoETHE és SCHILlER is levelezőtársa volt. DARWIN és HAECKEL is HuMBOLDT naplóját olvasva kaptak kedvet a világ felfedezéséhez. A környezetvédelem nála jelent meg először: a gyarmatosítók természetpusztítását megfigyelte, dokumentálta, sőt arra is felhívta a figyelmet, hogy a természetes növényzet eltávolítása befolyásolhatja a klímát. Tudományos „,sztár” volt: előadásai és közleményei olyan nyelvezettel készültek, amely népszerüvé tette öt - életének ez a vetülete mára feledésbe merült. Legjelentősebb eredménye a Kozmosz című műve, mely már halála után jelent meg. Megpróbálta teljeskörüen leírni Földünket a fizikai jellemzőitől az élővilágáig. Számos fajt neveztek el róla, de számos felszínforma (és egy áramlat, valamint egy holdi kráter) is nevét viseli. A Magyar Nemzeti Múzeum kertjében emlékköve van.

\section{KULI-RÉVÉSZ KITTI: Legeltetés kizárás hatása izeltlábúakra.}

Előadó első alkalommal tartott előadást a Szakosztályban. Diplomamunkája témáját mutatta be, amelyet a biodiverzitás megőrzése inspirált. Gyepes területeken extenzív kaszálással vagy legeltetéssel lehet fenntartani a diverzitást. Hipotézise szerint a legeltetés csökkenti az ízeltlábúak egyedszámát, de e csökkenés mértéke a talajközelben élő fajoknál kisebb, mint a vegetációban élőknél. Továbbá a különböző vegetációtípusok is hatással lehetnek a vizsgált taxonokra. Vizsgálatukat a Csanádi-pusztákon végezték, szikes réten és ürmöspusztán. Összesen $12 \mathrm{db}$ félhektáros területet jelöltek ki, melyekben fühálóztak és talajcsapdákat telepítettek. Közel 5000 pókegyedet gyüjtöttek talajcsapdával, rájuk elsősorban a vegetációtípusok eltérése volt nagy hatással: a szikes réten magasabb volt a faj- és egyedszám, mint az ürmöspusztán. A legeltetésnek - munkahipotézisükkel összhangban nem volt szignifikáns hatása. A fühálózott anyagban a poloskákat kutatták. Ennél a csoportnál a legeltetésnek szignifikáns hatása volt: a nem legeltetett területeken magasabb volt a faj- és az egyedszám, mint a legelés alá vont foltokban. A vegetációnak viszont csak majdnem szignifikáns hatását észlelték, valószínűleg azért, mert az ebből eredő különbségeket a kezelés hatása felülírta. A fajösszetétel eltért a kétféle társulásban. Összefoglalva az eredményeket megállapítható, hogy a különböző mikroélőhelyeken honos ízeltlábúak máshogy reagálnak a legeltetésre: a vegetációban élő poloskák diverzitását valóban jobban befolyásolta, mint a talajlakó pókokét; utóbbiakra a növényzet fajösszetétele volt nagyobb hatással. HORNUNG ERZSÉBET az elöadás után megkérdezte, hogy a pókokra lehetett-e hatással a kétféle társulás eltérő zsákmányállat-kínálata. Előadó szerint lehetséges, jó felvetés, érdemes lenne kutatni. SzÖVÉNYI GERGELY: Minden egyes poloska-egyedet meghatároztak, vagy csak a fühálós anyagban lévő példányokat? A pókok közül csak a talajcsapdázott példányokat vették figyelembe? KULI-RÉVÉSz KITTI: A poloskákat csak a fühálós, a pókokat csak a talajcsapdás anyagból vették be ebbe a vizsgálatba, habár minden anyagot eltároltak; határozásuk jelenleg is folyik. HERCZEG GÁBOR: Mi alapján helyezték el a mintavételi pontokat és sávokat az egyes területeken belül? KULI-RÉVÉSZ KITTI: Fő szempont volt, hogy legyen a lehatárolt területen belül és kívül, ill. a szegély mentén, annak külső és belső oldalán. GALLÉ RÓBERT kiegészítése: A határon történő átmozgások hatását is ki szerették volna mutatni, ezért a szegélytől lehető legtávolabb is jelöltek ki mintavételi pontot. HERCZEG GÁBOR: Inkább arra gondolt, hogy a talajcsapdák nem fedik le a terület nagy részét, nem tünik reprezentatívnak a mintavétel. Másik kérdése: A begyüjtött anyag teljes (összes taxont magába foglaló) diverzitását tervezik összehasonlítani? KULI-RÉvÉSz KITTI: Igen, de ez a jövő feladata lesz. SzŐCS GÁBOR: Hány évig mentek a kísérletek? KULIRÉVÉSZ KITTI: Egy éven át folytak. SzÖCS GÁBOR: Hosszabb időn át hogyan befolyásolhat- 
ja a legeltetés elmaradása a diverzitást, mit várnak? KULI-RÉVÉSZ KITTI: Mérsékelt zavarás növeli, de a teljes elmaradás csökkenteni fogja a diverzitást.

3. GALLÉ RÓBERT: Az élöhelytípus és a táji mátrix jelentösen befolyásolják a pókközösségek fajösszetételét és béta diverzitását.

Az alfa-diverzitás egy közösségen belüli diverzitást jelent, legegyszerübb méröszáma az adott élőhelyen előforduló fajok száma. A gamma-diverzitás a teljes régió diverzitása, az összes közösség teljes fajkészlete. A béta-diverzitás azt mutatja meg, hogy a különböző közösségek diverzitása egymáshoz képest hogyan alakul; talán legegyszerübben az alfa- és gamma-diverzitás mérőszámának hányadosával definiálható. Fő komponensei a beágyazottság (közös fajok) és a fajkicserélödés (eltérö fajok). Vizsgálatukat a Kiskunságban, homoki erdőssztyepp-foltokon végezték: nyílt homokpusztában kisebb-nagyobb erdőfoltok vannak. A foltok mérete nagyon erösen lecsökkent, ezeket ma faültetvények veszik körül. Összesen 18 foltot vizsgáltak: a gyepböl, az erdőből és a környező faültetvényböl egyaránt gyüjtöttek. Kérdéseik: A gyep elkülönül-e az erdőtől, ill. az ültetvény elkülönül-e az erdőtől a pókfauna tekintetében? Kb. 5600 pókegyedet gyüjtöttek, mindenhol szignifikáns különbséget találtak az egyes élöhelyek között. Az erdőben alacsonyabb, a gyepben magasabb a fajkicserélődés hatása, vagyis a gyepek igen izoláltak. A vegetációt és a hangyákat is vizsgálták, ugyanilyen eredményeket kaptak. A táj minőségének hatását is vizsgálták, ezeket természetességük szerint osztályozták. Azt találták, hogy a gyepekben volt a legkevesebb faj. Ezek mikroklímája ugyanis eltér a környező fás élőhelyekétől, amelyekben generalista erdőlakó pókok megtalálják életfeltételeiket, míg a gyepekben csak szükebb türésủ specialista fajok élnek. A táj minőségének szignifikáns hatása van a diverzitásra. Összefoglalva: az erdőssztyepp foltoknak egyedi pókfaunája van, melyeket még igen kis területi kiterjedésü foltok is képesek megőrizni. A gyepek pókjai izoláltabbak, mint a fás vegetációé, és diverzitásuk alacsonyabb, mint a fenyveseké. A megmaradt erdőssztyepp foltokat veszélyezteti a jármüvek általi taposás, beszántás, túllegeltetés, a környező faültetvények tájidegensége (pl. aljnövényzet teljes hiánya). SzÖVÉNYI GERGELY: Milyen időtávban zajlott a vizsgálat? GALLÉ RÓBERT: Egy éven át folyt. SzÖVÉNYI GERGELY: Mióta izoláltak ezek az erdőssztyepp foltok? Milyen volt régebben a köztük lévő vegetáció? GALLÉ RÓBERT: Nagyjából 50-80 éve izoláltak, azóta a méretük csökken. A fenyöültetvények gyakran felnyílnak, ilyenkor a gyepszintet visszafoglalhatja az eredeti vegetáció. Így dinamikus rendszerként lehet felfogni. SzÖVÉNYI GERGELY: Vannak olyan pókfajok, amelyek csak az igazán régi gyepfoltokban tudnak fennmaradni? GALLÉ RÓBERT: Néhány ilyen unikális faj létezik, de a vizsgált foltokban kevesebb van belölük, mint más, nem vizsgált területeken. Találtak egy valószínűleg még leíratlan fajt is. SzÖVÉNYI GERGELY: Van esély a területek megőrzésére? GALLÉ RÓBERT: Jelentős részük erdőtagban található, a bolygatás mellőzésével megőrizhetők. HORNUNG ERZSÉBET: A pókok felosztása generalistákra és specialistákra a habitatra vonatkozik? Elkészült-e a pókfajokra ez a beosztás? Az ászkák egy részére igen. GALLÉ RÓBERT: Jelenleg még nem lehet besorolni az összes pókfajt, lassan gyülnek ehhez az ismeretek, sokkal több információra lenne szükség.

4. BorbÁs MÁTÉ, PusKÁs Gellért és SzÖvÉNYi GERGEly: Az Alsó Neretva-völgy és környékének (Dél-Hercegovina) Orthoptera faunája és annak természetvédelmi értékelése.

Napjaink biodiverzitás-krízisének idején nagyon fontos adatokat gyüjteni a fajok elterjedéséről, élőhelyéről ahhoz, hogy természetvédelmi intézkedéseket hozhassunk megőrzésükre. Az Orthoptera rend diverz, jó indikátor, fajaik jól detektálhatók, így feltáró kutatások 
jó alanya lehet. 2016-ban elkészült az IUCN vörös listája az európai egyenesszárnyúakra. Legtöbb endemikus fajuk a Balkán-félszigeten honos, ezek $40 \%$-a védelmi beavatkozást igényel. Bosznia-Hercegovina tagolt felszínű ország, délröl mediterrán hatás éri, de faunája alig feltárt. Komplex terepi mintavételezést terveztek végezni, minden egyenesszárnyú fajra kiterjedően. Mintavételi területük Mostar-tól délre helyezkedik el, főleg síkvidéki területen. Fűhálóztak, egyeltek, akusztikusan észleltek és éjszaka lámpával kerestek. Adataikat és a korábbi irodalmi adatokat térinformatikai adatbázisba rendezték. Negyven mintavételi helyet jelöltek ki, a Google Earth program müholdképei alapján. Minél változatosabb élöhelyeket igyekeztek kijelölni. Összesen 680 adatot gyüjtöttek. Az irodalmi adatokat kritikai értékelésnek vetették alá, bizonyos fajokat törölni kellett a fajlistából, és követni kellett az időközben megváltozott taxonómiai viszonyokat. Összesen 28 fajt mutattak ki újként a területről, ezek közül három új az ország faunájára. Két fajnak számos előfordulását találták, így át lehet sorolni kisebb veszélyeztetettségü kategóriába. Különösen értékes élöhely volt egy mocsaras terület a csatlakozó üde rétekkel, ill. az ország rövid tengerparti szakasza. Sok adathiányos fajhoz nyújtottak új adatokat.

SzÖVÉNYI GERGELY az elöadás után lezárta az előadóülést és kellemes ünnepeket kívánt.

\section{4. előadóülés, 2020. február 5-én}

Az ülést NAGY PÉTER elnök úr vezette le.

1. Könyvbemutató: Magyarország nagylepkéinek határozója. Köszöntőt mond KoRsós ZOLTÁN, NAGY PÉTER és HERÉNyi MÁRTON.

KORSÓS ZOLTÁN (a Magyar Biológiai Társaság elnöke) szerint ez a könyv minden szempontból különlegesnek nevezhető, szerkezete formabontó: folyamatábra-szerüen müködő, sok illusztrációval ellátott. Ha ez a szerkesztési mód beválik, akkor a későbbiekben a határozókönyveket ilyen formában lehet majd elkészíteni. Kisebb hibája a könyvnek, hogy a végén lévő színes táblákon az egyedi fényképek túlságosan kisméretüek. Előadó végül sok sikert kívánt a könyv szerzőjének a továbbiakhoz.

NAGY PÉTER (az Állattani Szakosztály elnöke) örült annak, hogy a szerző a Szakosztály jegyzői feladatait is ellátja, és annak is, hogy a könyv a Szent István Egyetem nyomdájában készült. Ez az új formátumú könyv lehetőséget teremt arra is, hogy egy új, zoológiai témájú könyvsorozat első tagjává válhasson. Kiemelte, hogy szép számú hallgatóság jött el, és a megjelentek életkora igen változatos - akárcsak az előadóké.

HERÉNYI MÁRTON (az Ifjúsági Szakosztály - Fiatalok Természetismereti Klubja elnöke) kiemelte, hogy a Klub terepi munkái során olyan módszereket igyekeznek használni, amelyek középiskolások, esetleg felső tagozatos általános iskolások számára könnyen használhatók. Azonban az élölények határozása nem tartozik ezek közé: gond a kulcs szövegének értelmezése, és a végeredmény ellenőrzése. A könyv anyaga először egyes családokra írt külön-külön határozólapok formájában öltött testet. Ezeket a Klub programjain, iskolákban, állatrendszertani egyetemi gyakorlatokon tesztelték. Végül MECSNÓBER MELINDA, a Társaság ügyvezető igazgatója talált egy pályázati lehetőséget, ennek segítségével válhatott 
könyv-formátumúvá az anyag. Elöadó reméli, hogy a könyv hasznára lesz az oktatásnak, kutatásnak, természetformálásnak, hivatásos természetvédelemnek egyaránt.

\section{MERKL OtTÓ: Már megint egy lepkés könyv! Na, de milyen!}

Sok zoológus kutató pályája úgy kezdődik, hogy az első másfél-két évben az általuk kiszemelt csoportról összegyüjtött tudásuk után már úgy érzik, megírhatják életük fô müvét ennek eredménye olyan könyv, amely jobb lett volna, ha nem jelenik meg, és amely végigkíséri az adott csoport további kutatását. Ezért Előadó némi távolságtartással fogadta el a kézirat lektorálására történő felkérést, ám megnyugodott, mikor megtudta, hogy sok hosszú év munkája fekszik a könyvben, és sokat tesztelték a határozókulcsokat. Ha egy bogarászt felkérnek, hogy egy lepkés könyvböl beszéljen, akkor természetesen bogarakról fog beszélni. Néhány látványos bogárfaj létezik, de 95\%-uk igen apró - bezzeg a lepkék között sokkal több a látványos faj. A könyv előzményei között ABAFI-AIGNER LAJOS Magyarország lepkéi címü müvét mindenképp említeni kell. Hosszú idő után a XXI. században jelent meg újra több hazai, színes ábrákat tartalmazó lepkés könyv. Elöadó szerint egy határozókönyv attól határozó, hogy kulcsot tartalmaz, amelyben állításokra adott két-két válaszlehetőség közül kell választani. Az új könyv is így épül fel. A nagylepkékkel foglalkozik, ám ez a név a könyv értelmezésében egy eléggé széttagolt, nem egységes csoportot jelöl. A határozókulcsban nagyon hasznos, hogy rögtön a kérdés mellett van egy segító ábra. Főleg ott jelentős ez a segítség, ahol a bogarakhoz hasonlóan kicsi és egyszínű fajok között kell különbséget tenni. Előadó kiemelte a www.izeltlabuak.hu honlapot, mint nagy terjedelmü képanyag forrását. A tárgymutató megléte is pozitívum, mert sokszor ennek elhagyásával spórolnak a könyvkiadásban.

\section{TóTH BALÁzS: Magyarország nagylepkéinek határozója - hogyan készült?}

Ennek az előadásnak a témája főleg az volt, hogy a szerző hogyan állította össze a határozókulcsokat, milyen nehézségekkel kellett megküzdenie ennek során. Előadó a Fiatalok Természetismereti Klubjának programjain találkozott egy, vízi makrogerinctelen csoportokra készített, laminált határozólappal, amely nagyon könnyen használható; ez adta az ötletet a lepkehatározó elkészítéséhez. Abban az időben még nagyon kevés lepkés könyvet lehetett találni, az internet pedig éppen elkezdett terjedni. Elöször a legkisebb fajszámú lepkecsaládok kulcsai készültek el, különálló lapokon, majd később az egyre fajgazdagabb családok kerültek sorra. Végül azt a kulcsot is meg kellett írni, amellyel magukat a családokat lehet meghatározni, ill. amely megmondja, ha a kiszemelt példány molylepke, és határozásával nem érdemes tovább próbálkozni. Ezt a családhatározó kulcsot csak igen nehezen vizsgálható bélyegek (pl. szárnyerezet) szerepeltetésével lehetett összeállítani. Később a lepkék rendszertana családszinten változott, így e nehezen kezelhető kulcs még el is avult. Ezért Előadó a család-alapú csoportosítást nagyrészt elvetette, és hasonló kinézetü (a rendszerben egymástól távol álló) fajokból alkotott új csoportokat. Minden csoporthoz összeírta az oda illeszthető fajok listáját, majd keresett egy-két olyan egyértelmü bélyeget, amely ezt a faj-halmazt két, nagyjából egyforma méretü csoportra osztja. Addig osztogatta a kisebb alcsoportokat ezen a módon, míg eljutott az egyes fajokhoz. Az ilyen módon elkészült újraszerkesztés után hosszú időn át csak tesztelték a kulcsot egészen addig, amíg MECSNÓBER MELINDA rátalált az Agrárminisztérium pályázati lehetőségére és felajánlotta a Biológiai Társaság támogatását. Bár a pályázatot elnyerte a Társaság, a könyvkiadásban nem volt tapasztalatuk. Az A/4 méretben összeállított határozólapokat át kellett szerkeszteni A/5 formába, ami igen sokáig tartott. A szakmai lektorok szerepét a Magyar Természettudományi 
Múzeum munkatársai, BÁLINT ZSOLT és RONKAY LÁSZLÓ vállalták, a nyelvi lektor MERKL OTTÓ lett. Az átformázással párhuzamosan készültek el az ábraanyag (kb. 2000 ábra) alapjául szolgáló fényképek, a szerző barátainak jelentős segítségével (a képeket aztán a szerző dolgozta fel). A tesztelés tapasztalatai alapján egészült ki a könyv több fejezettel (és kb. 1000 fényképpel), már kitolt pályázati határidőre. Végül a lektori visszajelzések alapján módosította a kéziratot, és az így kialakult anyagot adta át a szerkesztőnek. Három korrektúra-forduló kellett ahhoz, hogy nyomdakésszé váljon a kézirat. Ám még a nyomtatás során is akadtak problémák, melyeket szerencsére sikerült éppen időben megoldani; pl. a hibajegyzékek nyomtatása a könyvbemutató napjának délelöttjén fejeződött be. A könyv a tervezettnél nagyobb példányszámban jelent meg, mert a Biológiai Társaság hozzájárult a nyomdaköltségekhez. A pályázati forrásból nyomtatott példányokat ingyen eljuttatták oktatási, kutatási intézményekhez, Nemzeti Parkokhoz; a saját költségén nyomtatott példányokat pedig a Társaság árulja. Előadó végül köszönetet mondott mindenkinek, aki segítette a könyv elkészülését. Az előadás után MERKL OTTÓ elmondta: a legtöbb határozókulcsnak az a hibája, hogy a tárgyalt csoport rendszertani viszonyait próbálja tükrözni felépítésében. Ez viszont felesleges, mert nem ez a dolga, és csak bonyolítja a munkát. Örült, hogy a szerző idejekorán feladta ezt a szerkezetet. NAGY PÉTER szerint eredeti és előrevivő gondolat volt mintaként tekinteni a laminált terepi határozólapokra.

4. SZENTIRMAI ISTVÁN és FARAGÓ ÁDÁM: Kutatástól a szemléletformálásig: lepkevédelem az Örségi Nemzeti Parkban.

Az Örségi Nemzeti Park Igazgatósága az országban egyedülálló módon sokrétűen közelíti meg a lepkevédelem problémáját. Az Örség lepkefaunája európai viszonylatban is kiemelkedő: sokféle élöhely van jelen, melyek a hagyományos tájhasználat miatt nagy területen fennmaradtak. Ám veszélyeztető tényezők is vannak: erdősülés, intenzívebbé váló élőhelykezelés, fragmentáció és a klímaváltozás. A lepkék védelméhez először is információkat kell gyüjteni róluk, elsőként a területek faunájának felmérésével. A ritkább fajokat célzottan keresték. Az éjjeli fajokkal később kezdtek foglalkozni, de most már rendszeresen lámpáznak - ám még a munka elején vannak. Élőhelykezelési vizsgálatokat is végeznek, melyekből megtudták, hogy a rétek kaszálásának időzítésére hogyan reagálnak a védett fajok; legjobb az egyszeres, nyár végi kaszálás. Így a lepkékre szabottan lehet alakítani a rétek kezelését. A változások monitorozását is elindították. A cserjésedett élőhelyeket helyreállítják. Ám az élőhelyek nagy része magánkézben van, így szemléletformálás, népszerüsítés is szükséges. Az Örségi Lepkekaland az érdeklődők széles rétegeinek szól, itt a látogatók testközelből tanulmányozhatják a lepkéket. Lepkés társasjátékot is készített az Igazgatóság. A LepkeHáló program önkénteseknek szól, hogy segítsék felmérni Vas megye lepkevilágát; munkájuk jól kiegészíti a Nemzeti Park tevékenységét. Nekik rendszeresen szakmai napokat tartanak. NAGY PÉTER arról érdeklődött, hogy az előadásban említett lepkés társasjátékhoz valahol hozzá lehet-e jutni. Előadó szerint kis példányszámban készült, környékbeli iskolások számára, a Nemzeti Parknál ki lehet próbálni. SzÉL GYŐzŐ: A sok, lepkéket megfogó érdeklődőnek nincs negatív hatása a rétek növényzetére (taposás) vagy magukra a lepke-egyedekre? SZENTIRMAI ISTVÁN: Valamekkora negatív hatás biztosan van, de ez eltörpül az információgyüjtés és szemléletformálás pozitív hatásai mellett. A lepkefajokat nem az egyes példányok megfogása, sokkal inkább az élőhelyek károsodása veszélyezteti. NAGY PÉTER: Észleltek-e már klímaváltozással kapcsolatos hatásokat? SzENTIRMAI ISTVÁN: Általános tendencia az élőhelyek kiszáradása, ez értékes élőhelyeket veszélyeztet. 
A patakok vízszintje is csökken. Ám nehéz bizonyítani az összefüggést, és még nehezebb a változások ellen tenni. Már tüntek el nedvességet kedvelő fajok a területről.

\section{SZERÉNYI GÁBOR: Határozók a közoktatásban.}

GOETHE, aki nemcsak költőfejedelem volt, hanem a természettudományban is maradandót alkotott, egyik esszéjében azt írta: a tudomány története a tudomány maga. Előadó szerint határozókönyv az, amely legalább néhány faj azonosításához segítséget ad. Ha így tekintünk a témára, akkor már ARISZTOTELÉSZ müve is határozókönyv: felvázolja az egyes élölénycsoportok közti hasonlóságokat és különbségeket. A középkori oktatásban még ezt a müvet használták. A korszak végén megszületik a könyvnyomtatás, amely felgyorsítja az információáramlást. A reformáció is ebben az időszakban zajlik, amely új szemléletet ad az élölények megismerésére. Magyarországon a középkorban alapítják az első iskolákat: ezek alsó, középső és felső tagozatból állnak. Utóbbi a mai középfokú oktatásnak felel meg, és ezen a szinten találkoznak természeti (fizikai, kémiai, biológiai) tárgyú ismeretekkel a diákok. A könyvnyomtatás a határozókönyvek (herbariumok, bestiariumok) virágzását is elhozza: sok ábrával, sok nyelven köznevekkel ellátva. Ekkoriban természettudományos egyetemi oktatás csak az orvosképzésben hozzáférhetö. Sokasodnak a könyvek, végül eljutunk LINNÉhez. Magyarországon MÁRIA TERÉZIA idején a természettudományos oktatásban főleg határozókönyvek vannak, ekkor jelennek meg az első határozókulcsos szerkezetü müvek. Ezután egészen 1980-ig csak némi összehasonlító anatómiát, de föleg fajismeretet tanítottak a magyar közoktatásban; csak attól az évtől kezdve szerepel etológia, ökológia, biokémia vagy sejtbiológia a tankönyvekben. De még mindig nem tudunk elszakadni a határozókönyvektől: segédanyagként jelenik meg ebben az évben a Kis növényhatározó. Az igény nagy volt az ilyen müvekre, amit a Búvár zsebkönyvek sorozat sikere igazol. Ám még ma is kapható a Növényismeret, a Kis növényhatározó utóda. A természetben való eligazodásra még ma is megvan az igény a széles közönségben is. NAGY PÉTER az ülés zárásaként megköszönte a Magyar Természettudományi Múzeumnak, hogy a helyszínt biztosította, valamint MECSNÓBER MELINDÁnak az ülés szervezéséért mondott köszönetet.

Az előadóülés végén lehetőség nyílt a könyv megvásárlására, melyet a szerző dedikált. 